\title{
2.6. PROBLEMATIC METHODOLOGICAL QUESTIONS OF INVESTMENT PROJECT EVALUATION
}

\begin{abstract}
Summary
There are some scientific questions related to the NPV and IRR which have not been worked up. From these issues, this paper discusses the economic content of the two categories and the questions of usability for project evaluation and ranking. The main research methods are methodological analysis, model editing and examination of the mathematical formulas. The paper proves that the NPV is the discounted amount of the surplus profit generated above the profit requirement, and points out, that content band of the real reinvestment rate assumption is fundamentally different from everything that can be found about this in the literature. Because of the NPVs are not comparable, the paper systematically eliminates the distortion effects. Thus, the NPV transforms into a special kind of rate, namely, the difference between the factual rate and the required rate of return. This NPV rate (with equal required rates of return) gives the same ranking list as the IRR. The aggregate capital needs is a new conception and gives a new viewpoint to analysis of investment projects evaluation. The paper defines the special content of aggregate capital needs and compiles an index number for it.
\end{abstract}

Keywords: NPV, IRR, ranking, aggregate capital needs, reinvestment rate assumption

\section{Literature review}

The paper examines the two main tools of investment project evaluation, i.e. the net present value (NPV) method and internal rate of return (IRR) method. Application appropriateness of the two methods is sharply debated from the first half of the last century. Many writings already were born in the 1950s (see Alchian, 1955; Solomon, 1956; Bierman and Smidt, 1957). Since then the discussion is running.

The literature of finance expresses a very determined preference for NPV. In spite of this, business professionals of developed countries apply the IRR in a large proportion for decision-making. For example Arnold and Hope (1990) cite two surveys done in the 1970s and 1980s, demonstrating that the largest British companies (that are otherwise able to pay the best experts) definitely rank the IRR higher than the NPV in practice. They mention that a lot of American surveys prove that the practice prefers the IRR in the USA as well. The practical method preferences are widely researched. Szücsné Markovics (2012) gives a literature review about the researches on methods which are used by companies throughout the world. Illés and Keszthelyi (1998), Illés (2000) and Daróczi (2004) examined the practical use of different methods based on empirical researches on the complex evaluation of decision-making process. According to my experiences, in business economics literature generally there is not a strong method preference, but the IRR method often seems to be better.

\section{Different disciplinary roots}

According to Volkman's (1997) research, the emergence of method qualification contradiction could be attributed to the fact that finance propagates the more 
advantageous nature of NPV method based on one of Fisher's works (Fisher, 1930) published in the first half of the past century while business economists (and business professionals) prefer the IRR method based primarily on the works of Boehm-Bawerk (1889) and Keynes (1936).

However, this is only the surface. Serious methodological contradictions are caused by the different disciplinary foundations. Finance, namely, is based on standard microeconomics, or as Volkman says "based on orthodox economic theory" (Volkman, 1997, p.75). Problems caused by microeconomic roots are mentioned by Woods and Randall (1989) as well. There is a significant difference between the theorems of finance and business economics as far as the proximity to real-life problems is concerned. Basically, there is no direct passage within microeconomics and business economics because of the very different abstraction level, different category system and different approach.

Microeconomics is not a business practice oriented science. The finance does not take this into account, and uses microeconomic categories and methods. In concerning methodological questions the finance-based findings and conclusions are based on two general assumptions: the investment opportunities are unlimited and the reinvestment rate is equal to the required rate of return. (Although these assumptions are regularly behind the finance models, it is not always stated clearly.) These conditions are never met in reality. That is why these doctrines should be lead through conditions that are close to reality before they are offered for corporate professionals.

The abstraction level of business economics is relatively low and a considerable part of its research results - adjusted to the characteristics of the given company - may be directly used in the corporate practice. The business economics literature often mentions the importance of the professional clarity and practical implications of the suggested methodology (e.g. Garrison, 1988, p. 712; Arnold and Hope, 1990 p. 260; Schmalen, 2002, pp. 602-605). That is, the majority of the business experts can only apply the methodology correctly if they can fit methods to their way of thinking, and if they can somehow connect them to the logic of the economic process.

\section{The arguments for superiority of NPV}

There are no strong and methodically supported arguments to demonstrate the primacy of the NPV over the IRR. The literature puts forward three particularistic arguments to change things around. One of them is that the NPV means also that amount, which will be added to the shareholder value by the project. The second argument is based on the reinvestment rate assumptions. The third one is that there only one NPV can occur as opposed to the opportunity of several IRR.

\section{NPV as a shareholder value surplus}

Among the advantages of NPV, finance literature regularly mentions the theorem according to which the NPV indicates the project's contribution to the shareholder value (e.g. Van Horne and Vachowicz, 2008; Crundwell, 2008). The publications often refer to Fisher's related theorem.

There are also a considerable number of authors who interpret the NPV primarily or simultaneously as the surplus of company (or firm) value (Keane, 1975; Baker and 
Powell, 2005; Laux, 2011). However, in the reality (as it is well known) the shareholder value is not equal with the firm value, and the maximization of the firm value is not the same as the maximization of shareholder value.

The paper of Woods and Randall (1989, p. 85) says that the direct relationship of NPV and shareholder wealth has never been proven:("the links between NPV and shareholder wealth are not made explicit in the literature. Textbooks merely state the equivalence as a general premise without rigorous proof'). The theorem are still alive today, even though it cannot be proven moreover it contains many logical contradictions (Illés, 2012b).

\section{The reinvestment rate assumptions}

According to the main direction of reinvestment rate assumption the NPV method assumes the required rate of return, while the IRR method assumes the IRR as the reinvestment rate of annual yields (as long as the project lasts). The debate about this began in the 1950s (Solomon, 1956; Renshaw, 1957), and is still underway.

The contested conception emerged as a kind of treatment of the ranking conflict which often occurs between the NPV and the IRR. The supporters of the described above reinvestment rate assumption concept ensure automatic priority to the NPV method by emphasizing that reinvestment according to the high IRR is hard enough (a typical example is Laux, 2011).

The debate is slightly one-sided. One of the dominant groups does not argue and does not react to the opposing views, just repeats the validity of the reinvestment rate assumption as a well-known relationship. These views can be considered roughly uniform. The representatives of the significantly smaller group of those who partially or fully reject the reinvestment rate assumption try to prove that this assumption is wrong. They use different logical arguments as well as mathematical or exemplary evidence. Their methodical solutions are also varied (e.g. Dudley, 1972; Carlson et al., 1974; Keane, 1979; Lohmann, 1988; Johnston et al., 2002; Crean, 2005; Rich and Rose, 2014).

In a great number of studies in this topic, many unclear conditions, categories and phrases can be found. For instance, the reinvestment rate assumption itself is interpreted as either an explicit, implicit, or some kind of general assumption. The type of reinvestment amount is not always obvious, either. These amounts can mostly be interpretable as yields coming from a project in different years of its duration, more rarely as differences computed from yields of two examined projects. Sometimes the examined problem is not actually the reinvestment rate assumption, but the critical reinvestment rate (e.g. Alchian, 1955; Dudley, 1972; Meyer, 1979). In the latter cases, references date back to Fisher (1930). Meyer's paper (1979) examines this question according to the system tools and categories of microeconomics.

Several authors point out their disapproval with the one-sided teaching of faulty doctrines. Among them, Johnston et al. (2002) call attention to the fact that a number of finance textbooks completely ignore scientific findings that disprove the reinvestment rate assumption of the two methods. Due to this, they urge reforms. In the introduction of their paper, Walker et al. (2011) give a detailed description of teaching completely controversial materials. Their research joins to the study of Keef and Roush (2001), which draws the attention to the fact that finance textbooks use the 
reinvestment rate assumption higher proportion than textbooks in management accounting. The findings of their own research done a decade later show a similar direction. They make an important statement emphasizing the lack of consistency amongst disciplines: "Finance books fall at one end of the continuum with 64 percent using the assumption while the engineering economics books fall at the other end with just 20 percent using the assumption" (Walker et al., 2011, pp. 11-12).

In my research results, this sort of reinvestment rate assumptions as an automatism of these methods has never proved.

\section{Only one NPV can occur}

The argument that there only one NPV can occur as opposed to the opportunity of several IRR sometimes appears as comprehensive problem (Brealey and Myers, 1988). However it is generally known that, the multiple internal rates of return occur only in cases of unorthodox cash flow patterns. According to the general academic opinion, the NPV method is suitable for evaluation in the case of unorthodox (non-normal) cash flow patterns as well, as there can be only one NPV as opposed to the opportunity of several internal rates of return (e.g. Arnold and Hope, 1990; Bierman and Smidt, 2012). However, there is absolutely no evidence that the NPV of an unorthodox cash flow pattern shows a real economic content.

\section{Literary trends in preferring of NPV method}

In the literature a sort of harmony appears on the issue of project classification, that both the NPV and IRR method will always give the same result, either rejecting or accepting a project (e.g. essentially the same is discussed by Bierman and Smidt, 1986; Brigham and Ehrhardt, 2008; Khan and Jain, 2008; Kinney and Raiborn, 2012). This consistency, however, does not limit the declarations concerning the NPV's superiority. Behind the NPV preference, three main trends with a slight boundaryblurring can be revealed as follows:

1. The NPV method is the best in all aspects. Most of the representatives of the trend according to which the NPV is the best as a selection tool and as a ranking creating tool as well apply the above shareholder value concept as a kind of guiding principle. There is a very interesting "forecast". Laux (2011) says that academics consider the NPV approach is superior and some of them so find that over time practitioners have come to agree.

In fact, the Fisher's intersection was borne on the basis of comparability of NPVs as well (Fisher 1930). The Fisher's intersection is named the point where NPV curves of two investment projects are equal. This intersection is often referred as a decision preparing problem nowadays as well (Baker and Powell, 2005; Hill, 2008; Van Horne and Vachowicz, 2008). Several decades now known that the NPVs are not directly comparable. Generally, the comparability is distorted by the differences of initial investment, durations and the rapidity of payback (Keane, 1975). Despite of this, the one-sided recommendation of NPV has not disappeared.

2. The NPV is the best as a selection tool, but the NPV divided by the initial investment (or the profitability index) is suitable to be a ranking creating tool. The NPV divided by the initial investment and the profitability index gives the same ranking. Namely, 
the profitability index can be written in the following form as well: [1+ NPV divided by the initial investment]. For example Brealey and Myers (1988), Albrecht et al. (2007), Watson and Head (2009) suggest the profitability index for ranking creating. The paper of Damodaran (2010) suggests for this purpose the NPV divided by the initial investment, however, this rate there is named profitability index. By these suggestions only the distortion effect of differences in initial investments is avoided (two of distortion affects are remained).

3. The NPV is the best as a selection tool, however, the equivalent annual average sum of the NPV is suitable to be a ranking creating tool. This ranking tool suggestion often appears - mainly in the financial literature - in the last three decade (e.g. Helfert, 1991; Baker and Powell, 2005; Lee at al., 2009). The way of quantifying the average is NPV divided by the annuity factor, which in business economics means multiplying by the loan repayment factor. (Business economics always uses the loan repayment factor. The financial literature uses the annuity factor, which is the reciprocal of the previous formula.) This solution only eliminates the distortion effect of the differences in duration (two of them are remained).

In the literature, it does not seem ambition to simultaneous eliminate the three distorting factors.

\section{Purpose and method}

The main objectives of this paper are as follows:

- To define the economic content of the NPV and IRR and to diagnose the usability for project evaluation and ranking.

- To present the profit requirement calculation according to required rate of return.

- To define the special content of aggregate capital needs, to compile an index number for it, and to highlight the importance of taking the aggregate capital needs into consideration.

- To show the essentials of the real reinvestment rate assumption in case of orthodox cash flow pattern.

The main research methods are methodological analysis, model editing and examination of formulas. The proving ways of findings are logical and mathematical processes as well. The interests of clarity, the paper uses the following conditions and categories:

1. The traditional concept of the NPV and the IRR methods: The paper interprets and analyses the content background of NPV and IRR methods in the classic sense. Among others, the paper uses the term "capital" as a homogeneous sum in terms of ownership (and as investable or invested money). Profit is interpreted as a pre-tax profit. The interpretation and analysis of methods are related exclusively to investment projects.

2. Business economics approach and system of aspects: The business economics interprets and manages the database as well as the results of calculations according to the conditions in reality. (As featured in the first section finance is inherently built on standard microeconomic foundations.). This study examines the NPV and IRR from the aspect of business economics by using its category system.

3. The calculation logic follows the real process of management and after the close of this, returns to the discounting method: The paper assumes that the management 
relations can be clarified moving forward in time according to the management process. The planning and thinking of corporate executives works the same way. The main and well-known question of strategy making is: "where are we now and where we want to arrive?" It would be difficult to work out backwards this. The moving forward is the only way in which the emergence and realization of return requirements as well as the process of the surplus profit formation can be seen through. Therefore, this study uses a detour to substitute for the classical methods. In order to show the content tally with the classical methodology of project evaluation, after the systematic exploration of content relations, the analysis returns to the classical method. Discounting back to the start time makes the content examination of the return process impossible.

4. The NPV and IRR methods can provide acceptable and economically meaningful outcomes only in case of orthodox cash flow patterns: (This is proved by Illés 2016.) Therefore the analyses and conclusions are only concerning to the cases of investment projects with orthodox cash flow patterns. (The well-known criteria of orthodox cash flow patterns are: a series of the difference of annual revenues and expenditures starts with negative amount or amounts and the sign of these differences changes only once. That is, from a point in time where this difference first turns into positive, this positive sign does not change.)

5. Yield analysis according to the return structure: Examinations and analyses of the return process can be solved by following the formation of internal structure of the yield. The yield is the difference between the annual revenues and annual expenditures. So the yield belongs to the types of annual indicators. A positive amount of yield is surplus sales revenue in terms of financial needs in a given year. Therefore the yield exits from the project at the end of the examined year. The conditions of further utilization of this usually do not affect the evaluation of the analysed project. In the case of orthodox cash flow patterns, the content of the yield with a positive sign can consist of capital return and/or profit. In the NPV method, the profit part of the yield may consist of further two parts: profit according to the required rate of return and surplus profit. Until meeting the return requirements, the yield consists of profit according to the required rate of return and capital return. After the fulfilment of return requirements, the content of the emerging yield is surplus profit. In the IRR method, the yield all along consists of capital return and profit according to the interest rate, there is no surplus profit. In this case, collation with the return requirements takes place after calculations.

\section{The economic contents}

\section{The economic content of IRR}

Earlier in business economics the IRR was named time-adjusted rate of return (Garrison, 1988). IRR calculation means searching for the rate of return which makes the sales revenue line and the expenditure line equal to each other. (IRR is usually determined by a process of trial and error. Using computer the calculation is very quick.) In case of investment projects with orthodox cash flow patterns, the IRR shows the factual time-adjusted profitability rate of the investment. This content is regarded generally known in business economics literature. For instance Garrison (1988) and 
Arnold and Hope (1990) interpret this rate as a true yield percentage. (This sort of content approach is not typical in finance literature.) The acceptability criteria of the project are decided by how large factual profitability rate is generated compared to the required rate of return. The difference shows how large surplus rates (or lack of rates) are generated compared to the required rate of return. Generally, this difference needs not be defined numerically; this becomes visible when writing the two rates next to each other. Where the two rates are equal, that still means that required profitability is exactly achieved.

Having more than one IRR is the characteristic of unorthodox cash flow pattern projects only. It is occurs that financial literature does not handle the distinction of orthodox and unorthodox cash flow patterns and denies the expedience of the IRR (e.g. Brealey and Myers, 1988). It often says that the IRR is without meaning (Hill, 2008). These statements are valid only the case of unorthodox cash flow patterns. In this case the multiple IRRs in reality are only technical factors, and they really are without economic meaning.

\section{The economic content of NPV}

The NPV literature does not deal with economic content clarification. According to my research results, the economic content of the NPV is clear only in case of orthodox cash flow patterns. In this case, the NPV is the sum of the surplus profit generated above the required one, discounted for the present time. This is explicable in logical way and demonstrable mathematically as well (Illés, 1990, 2007, 2012a).

\section{Two basic formulas}

In well-known theory, the NPV is calculated so that the discounted sum of all expenditures is subtracted from the discounted sum of sales revenue that is associated with the examined investment project. The calculation can also be made with the time series of the difference of revenues and expenditures. Then the annual differences are discounted and summarized. Hereinafter, in order to simplify modelling, that sort of model will be examined where the payment of initial investment occurs at the same time as operation is started. This is date zero. The first revenues will occur one year later, by this time the annual revenues exceed the annual expenditures. The two basic formulas of NPV method are used in this paper are as follows:

$$
N P V=\sum_{t=1}^{n}\left(B_{t}-K_{t}\right) \frac{1}{(1+i)^{t}}-E_{0} \quad \mid B_{t}-K_{t}>0
$$

Where

$B_{t}=$ sales revenues in year $t$,

$K_{t}=$ expenditures in year $t$,

$E_{0}=$ initial investment (the investment sum is occurring in the zero point of time),

$i=$ required rate of return,

$t=$ serial number of years,

$n=$ duration of the project.

$$
N P V=-E_{0}+\sum_{t=1}^{n} H_{t} \frac{1}{(1+i)^{t}} \quad \mid H_{t}>0
$$


$H_{t}=$ difference between sales revenues and expenditures in year $\mathrm{t}$ (where $\mathrm{Ht}>0$ for orthodox cash flow pattern projects).

According to NPV method the investment project is acceptable if the NPV is not less than zero. In the following the analysis deals with positive or zero NPV.

\section{General demonstration}

The economic efficiency of investment projects can be examined correctly by several methods, not only by the published ones. Such a no familiar method can be the return calculation based on following up the return process. At the end of this process the output is the sum of surplus profit (according to all of annual surplus profits is charged with the required rate of return by the end of the duration). The essence of the proof is that the discounting of this surplus profit leads to the NPV.

The first stage of the demonstration describes the return process of the cost of capital. The cost of capital is the sum of the return requirement of the capital face value and its required profit according to the required rate of return.

The amount of the cost of capital not yet returned and the return status is

at the end of Year 1: $-E_{0}(1+i)+H_{1}$

at the end of Year 2: $\left[-E_{0}(1+i)+H_{1}\right](1+i)+H_{2}$

at the end of Year 3: $\left\{\left[-E_{0}(1+i)+H_{1}\right](1+i)+H_{2}\right\}(1+i)+H_{3}$

and so on. After the return requirement is met, the formula becomes positive. Assuming that the return status at the end of Year 3 already shows the pattern of the development of the process through time, the simplification is introduced.

Eliminating the curly and square brackets:

$$
-E_{0}(1+i)^{3}+H_{1}(1+i)^{2}+H_{2}(1+i)+H_{3}
$$

The numerical definition of the return status inscribed for the end of Year 3 can be applied further for the full duration of the investment:

$$
-E_{0}(1+i)^{n}+H_{1}(1+i)^{n-1}+H_{2}(1+i)^{n-2}+\ldots+H_{n-1}(1+i)+H_{n}
$$

In the second stage of the demonstration the surplus profits calculated above to the end of duration is transformed into present value. The three steps of it are: prescribing the discounting formula, fulfilling the discounting process, simplifying the resulted formula.

$$
\begin{gathered}
{\left[-E_{0}(1+i)^{n}+H_{1}(1+i)^{n-1}+H_{2}(1+i)^{n-2}+\ldots+H_{n-1}(1+i)+H_{n}\right] \frac{1}{(1+i)^{n}}} \\
-E_{0}+H_{1} \frac{1}{(1+i)}+H_{2} \frac{1}{(1+i)^{2}}+\ldots H_{n-1} \frac{1}{(1+i)^{n-1}}+H_{n} \frac{1}{(1+i)^{n}} \\
-E_{0}+\sum_{i=1}^{n} H_{t} \frac{1}{(1+i)^{t}}
\end{gathered}
$$

The Formula (6) has arrived at one of the basic NPV formula that is the Formula (2). The proof is complete. The deduction proved that in the case of orthodox cash flow 
pattern projects the NPV is the discounted amount of the surplus profit generated above the profit requirement according to the discount rate (Illés, 2012a).

The economic background of the NPV curve

The NPV curve is well known (Figure 1). The plotting of this is a regularly appearing topic within the literature of investment projects evaluation. The authors also consider that this figure is well-known and widely used; therefore do not use any professional reference. The figures and related explanations are introduced from different perspectives: once a general theoretical relationship (Arnold and Hope, 1990), another time as a solution of an exercise or an introduction of a problem through an example (Brealey and Myers, 1988; Van Horne and Wachowicz, 2008).

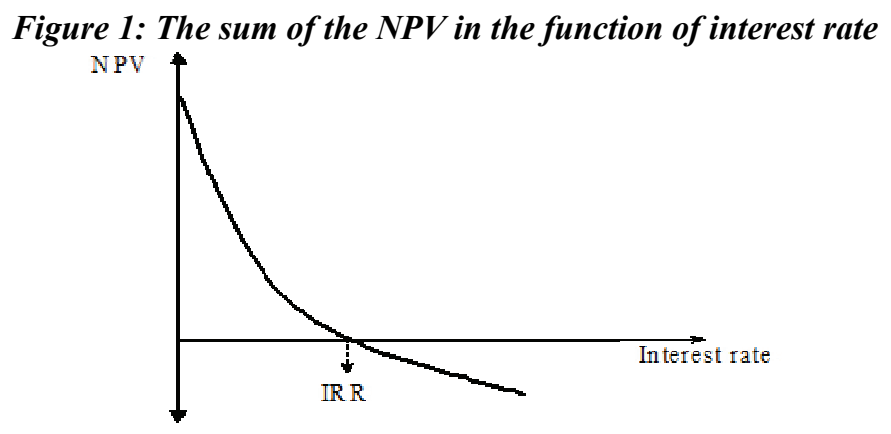

Source: Widely used illustrations of the relationship (e.g. Arnold and Hope, 1990, p.254,

Brealey and Myers, 1988, p. 79; Van Horne and Wachowicz, 2008, p. 329)

Figure 1 shows the NPV curve. By this the higher the interest rate is, the smaller the NPV. As a result of increasing interest rate, this decrease first reaches the zero NPV, then further increasing results in higher and higher negative NPVs. The interest rate that is at the intersection of axis $x$ and that results in zero NPV is the IRR. (This is well known.) As I know, there are no literature sources on the pre-conditions and detailed content background of the illustrated relationship. In order to specify the problem it must be laid down that the curve in Figure 1 is valid for most but not all projects in question. The relationship is only valid for profitable projects with orthodox cash flow pattern. Namely, the NPV is monotonously decreasing, there is only one intersection, and the curve starts in the positive range (Illés, 2014).

The illustrated NPV curve starts from zero percent interest rate. When the required rate of return is zero, then the NPV is calculated by the Formula (1) as follows:

$$
N P V=\sum_{t=1}^{n} B_{t}-\sum_{t=1}^{n} K_{t}-E_{0}=M \quad \mid i=0
$$

$M=$ Total accounting profit that is the difference of the nominal value of total revenues and total expenditures including initial investment arising during the whole duration of the project.

As Formula (7) shows, at zero percent interest rate the NPV is the difference between the nominal value of total revenues and total expenditures including initial investment. 
This difference can also be considered as an accounting profit summed up in nominal value for the total duration of the project. This gives the conclusion that if no profit is gained at nominal value, the starting point of NPV curve cannot be in a positive range. (Because of this, the figure is not valid for projects that do not generate accounting profit.)

The profit calculated at nominal value for the whole duration means the coverage possibilities of the profit requirements. If the profit requirements are not larger than the nominal value of all accounting profits, then the project is acceptable.

\section{Calculation of profit requirement}

The profit requirement is interpretable on the yearly sums of not returned part of initial investment. The not returned capital can be only within the pay off period (when the NPV is not negative). In the remaining years of the duration there is not profit requirement, therefore the yields of these years are surplus profits.

Calculation mechanism of the profit requirements according to the not returned part of initial investment (after the payback period the sum of the not returned capital is zero):

In the first year: $M_{s 1}=E_{0} i$

In the second year: $M_{s 2}=E_{l} i ; \quad$ where $\quad E_{l}=\left|H_{1}-E_{0} i-E_{0}\right|$

In the third year: $M_{s 3}=E_{2} i \quad ; \quad$ where $\quad E_{2}=\left|H_{2}-E_{l} i-E_{l}\right|$

For the $\mathrm{t}>1$ year generally:

$$
M_{s t}=E_{t-1} i \quad ; \quad \text { where } \quad E_{t-1}=\left|H_{t-1}-E_{t-2} i-E_{t-2}\right|
$$

$E_{t}=$ the not returned part of initial investment at the end of year $t$,

$M_{s t}=$ the profit requirement in year $t$ according to the not returned part of capital and required rate of return,

If the yearly profit requirement is larger than the yield in current year, then the difference is automatically added to the capital still to be returned. According to Formula (11) the total profit requirements that arise during the duration of the project can be calculated as follows:

$$
\sum_{t=1}^{n} M_{s t}=\sum_{t=1}^{n} E_{t-1} i \quad \text { where } \quad E_{t-1}=\left|H_{t-1}-E_{t-2} i-E_{t-2}\right|
$$

\section{The calculation of surplus profits and its present value}

In the last ear of pay-off period the economic content of yield consists of three elements: profit return according to required rate of return, capital return and surplus profit. On this basis Formula (13) describes the calculation of surplus profit concerning the final year of the pay-off period.

$$
H_{z}-\left(E_{z-1} i+E_{z-1}\right)=\Delta H_{z} \quad \mid H_{z}>E_{z-1}(1+i)>0
$$

$z=$ number of years of the pay-off period (including the last commenced year).

$\Delta H_{z}=$ sum of the surplus profit in the last commenced year of pay-off period.

The yield occurring in the years after the return totally consists of surplus profit. The 
description of its quantification begins by making formula for the calculation of the annual amounts. The sum of the surplus profit at the end of the first, the second and the third year after the pay-off period:

$$
\begin{array}{ll}
H_{z+1}+\Delta H_{z}(1+i) ; & H_{z+2}+\left[H_{z+1}+\Delta H_{z}(1+i)\right](1+i) ; \\
H_{z+3}+H_{z+2}+\left[H_{z+1}+\Delta H\right. & \text {; }(1+i)](1+i))(1+i)
\end{array}
$$

Considering the third year's formula, the sum of all of annual surplus profits charged with the interest rate can be calculated by the end of the duration as follows:

$$
F V \Delta M=\sum_{j=1}^{s} H_{z+j}(1+i)^{s-j}+\Delta H_{Z}(1+i)^{s}
$$

$F V \Delta M=$ the sum of the surplus profit charged with interest rate at the end of the duration,

$j=$ the ordinal number of the years of operating period after the pay-off,

$s=$ the number of years of the operating period after the pay-off $(s=n-z)$.

Because of the interest rates are charged, Formula (14) contains some false interest income. According to Formula (15) the false interest income falls out during discounting. Surplus profits will be discounted from the year of their occurrence. The present value of the discounted and summed surplus profits is the NPV itself:

$$
N P V=\left[\sum_{j=1}^{s} H_{z+j}(1+i)^{s-j}+\Delta H_{z}(1+i)^{s}\right] \frac{1}{(1+i)^{n}}
$$

$n=$ duration of the project $(z+s)$.

After simplification [using $(\mathrm{n}=\mathrm{s}+\mathrm{z})$ ] there will be a clear formula, according to which the NPV can be reached by discounting and assuming the surplus profits according to the date of occurrence:

$$
N P V=\sum_{j=1}^{s} \frac{H_{z+j}}{(1+i)^{z+j}}+\frac{\Delta H_{z}}{(1+i)^{2}}
$$

Starting from the classical version of the NPV inscription it cannot be seen that only surplus profits remain among the really discounted items.

\section{The real reinvestment rate assumption in the case of orthodox cash flow pattern}

According to the logic of time going forward, firstly the capital and profit requirements should be recovered. These items gradually quit the project and calculations, according to their return. (The method does not charge farther return requirements for these items.) The yields generated after the fulfilment of return requirements are the surplus profit. These sums also leave the project so they cannot be regarded as the organic part of the project. However, these sums remain in the calculations. The NPV method focuses on the quantification of sums interpreted in this paper as surplus profit.

The discounting mechanism related to the surplus profit automatically assumes that the profitability of this surplus will be equal to the required rate of return according to the project. This way the real reinvestment rate assumption will prevail, but only regarding 
the surplus profit appearing above the profit as to the required rate of return.

It is important to emphasize that the this real assumption concerns only the surplus profit and it concerns neither the total yield, nor the yield part for capital return, nor the yield part for return on profit requirement. The content band of the real reinvestment rate assumption is fundamentally different from everything that can be found about this in the literature. The real reinvestment rate assumption exclusively is prevailed for the surplus profit. This does not cause any inconvenience. For orthodox cash flow patterns the IRR method does not enforced any reinvestment rate assumption. The IRR covers the whole profit sum, so technically there is no surplus profit (no lack, either). Accordingly, the automatic reinvestment rate assumption cannot be realized.

It should be noted that in the case of unorthodox cash flow patterns the real reinvestment rate assumption are enforced in both method. Here the significance of this may be very large. In this area there are loss-making projects with positive NPV. However, in the case of orthodox cash flow patterns the loss-making projects are automatically rejected by both methods. The most important point of the problem is as follows: the calculation mechanism of the NPV method handles the false interest incomes of temporary surplus profit as real money. Discounting the unused part of the false interest income leads to a positive NPV. The NPV emerging this way is false as well. Detailed proof and analysis of these are in Illés, 2016)

\section{Comparison of expressive power of the two indicators}

The economic content of the IRR of orthodox cash flow pattern is clear. This is the profitability rate of invested capital. This information is in accordance with an almost commonplace basic truth of economics, that in the competitive market the capital goes where the highest return rate can be achieved at a given risk.

In contrast with this, an NPV with positive sign has the following message for the decision-maker: the profit requirements according to the required rate of return will be fulfilled and surplus profit calculated in present value will also be gained. If the question is whether the profit requirements are fulfilled, this answer is satisfactory. But it is not easy to tell what advantage this amount exactly means.

A quite ordinary example: for an individual who is fixing 300,000 euro in a bank for one year, it is more meaningful to do so at an interest rate of $4.5 \%$ than to be told that he will get 3\% interest on his deposit plus 4,500 euro more. This special sort of deposit is more difficult to see through with a long-term commitment (Illés, 2012b).

\section{The ranking problem}

As it was mentioned in the first section, the comparability of NPVs may distort the differences in initial investments, the durations and the rapidity of capital returns. There are literary sources for suggestion of certain corrections to eliminate of the distortion effects. These suggestions, however, only concern for the first or the second out of the three distortion effects listed above. (There is no visible pursuit of a complex correction.) 
The suggestion for dividing the NPV by the initial investment $\left[\frac{N P V}{E_{0}}\right]$ or using the profitability index $\left[1+\frac{N P V}{E_{0}}\right]$ as a ranking tool, eliminates only the distortion effect of differences in initial investments.

The suggested equivalent annual average sum of the NPV as a ranking creating tool only eliminates the distortion effect of the differences in duration. The formula of this time-adjusted average is: $q_{n} N P V \quad$ (where $q_{n}$ is the loan repayment factor, within the required rate of return and duration of the project).

Another step could be - although I did not find any suggestions for this in the literature - merging of the above two methods, that is, the numerical definition of the equivalent annual average sum of the NPV divided by initial investment, that is $q_{n} \frac{N P V}{E_{0}}$.

In the last formula there are eliminated distortion effects of initial investments and durations, however, there is no eliminated the distortion effect of return rapidity. The methodological elaboration of calculating a coefficient which could measure return rapidity seems to be very complicated in this structure. I believe that the calculation of this coefficient is not necessary, but very important to know its essence.

Fundamental cases: a) Return by years is uniform. Than the coefficient is 1. b) Return is quickly. The larger yields arise at the beginning of the duration. In this case the coefficient is bigger, than 1 (advantageous). c) Return is slow. The larger yields arise at the end of the duration. In this case the coefficient is lesser, than 1 (disadvantageous).

The cleansed formula is as follows:

$$
q_{n} \frac{N P V}{E_{0}} \lambda=(r-i) \varepsilon
$$

$\lambda=$ coefficient of payback rapidity,

$r=$ internal rate of return,

$\varepsilon=$ miscalculation factor.

The cleansed NPV is a special rate-difference between the factual return rate and the required one. This content is followed from exhibited calculating procedure. The ratecharacter has appeared when the NPV was divided by initial investment. The matter of rate-difference is following from that, the NPV is a surplus yield. Multiplying this surplus yield rate with the loan repayment factor it transforms the time-adjusted average of NPV rate. The last step is the correction with the coefficient of return rapidity. This way has formed the modified difference between the IRR and the required rate of return. This method cannot lead to the accurate difference of two rates. This is coming from the special cleaning solution in which are mixing the elements of static and dynamic procedures for investment project evaluation. This is indicated by a calculation error factor (Illés, 2012a).

The surplus profitability over the required rate of return (if the required rate is equal for all examined project) will be the highest for the project where the IRR is the highest. Thus the same projects will gain the first, second, etc. place in both rankings. In this correct way, there is not methodological superiority. 


\section{Aggregate capital needs}

The project's aggregate capital needs means the amount of capital needed for operation of the project during its full duration. This is a new business economics category. Quantification and consideration of it could significantly improve the economic evaluation and comparison of investment projects. The sum of the aggregate capital needs depends on the initial investment, duration of project and the rapidity of capital return. For the calculation it shall be aggregated the yearly tied-up capital that is the not-returned parts of the initial investment for each year (Illés, 2014).

The calculation method of tied-up capital for the first three years and for the $t>1$ year generally are presented in Equitation (8) - (11). Based on all these, the index number of aggregate capital needs $\left(E_{A C N}\right)$ is as follows:

$$
E_{A C N}=\sum_{t=1}^{n} E_{t-1}
$$

Tied-up capital is a state indicator, and therefore the tied-up capitals of different years cannot be summed up from this aspect. However, in consideration the incomeproducing potential needs to take into account simultaneously the tied-up capital and tied-up time. The content of the index-number means a capital amount which is tied up for one year. So the measurement unit of this is one unit tied-up capital for one year. According to the calculation method used above a three-year tie-up of one capital unit is equal to three capital units tied up for one year.

This solution is considered to be correct because the tied-up capital is computed with a database where in the first step the profit requirements are subtracted from the yields of certain years. The remainder is interpreted as a return part of initial investment in a given year.

It is useful to examine how much total capital is used in an investment project, to generate a given NPV and a given IRR. It is favourable if smaller aggregate capital needs result in a higher NPV or greater aggregate capital needs result in a higher IRR. The category of the aggregate capital needs has a significant opinion-forming role. It is advisable to take into account the aggregate capital needs as well.

\section{References}

1. Albrecht, W., Stice, J., Stice, E., Monte Swain, M. (2007): Accounting: Concepts and Applications. Cengage Learning Thomson South-Western

2. Alchian, A.A. (1955). The Rate of Interest, Fisher's Rate of Return over Costs and Keynes' Internal Rate of Return. American Economic Review, 45(5), 938-943.

3. Arnold, J., Hope, T. (1990): Accounting for Management Decisions. Prentice Hall International (UK) Ltd.

4. Baker, H. K., Powell, G. E. (2005): Understanding Financial Management: A Practical Guide. John Wiley \& Sons. USA, UK, Australia

5. Bierman, H., Smidt, S. (1957): Capital Budgeting and the Problem of Reinvesting Cash Proceeds, The Journal of Business, 30, No. 4: 276-279.

6. Bierman, Jr. H., Smidt, S. (1986): Financial Management for Decision Making. Macmillan, New York 
7. Bierman, H., Jr., Smidt, S. (2012). The Capital Budgeting Decision: Economic Analysis of Investment Projects (9th ed.) Routledge.

8. Boehm-Bawerk, E.V. (1889): Positive Theorie des Kapitales. Jena: Fisher.

9. Brealey, R. A., Myers, S. C. (1988): Principles of Corporate Finance. (Third edition.) McGraw-Hill Publishing Company, New York, St. Louis, San Francisco etc.

10. Brigham E. F., Ehrhardt M. C. (2008): Financial Management: Theory \& Practice. Thomson South-Western, Mason, USA

11. Brigham, E. F., Houston J. F.(2009): Fundamentals of Financial Management. South-Wesern Gengage Learning, Mason, USA

12. Carlson, C.R., Lawrence, M.L., Wort, D.H. (1974): Clarification of the Reinvestment Assumption in, Capital Analysis. Journal of Business Research. Volume 2, Number

13. Crean, M. J. (2005): Point of View. Revealing the True Meaning of the IRR via Profiling the IRR and Defining the ERR. Journal of Real Estate Portfolio Management. Volume 11, Number 3, pp. 323-330.

14. Crundwell, F. K. (2008): Finance for Engineers. Evaluation and Funding of Capital Projects. Springer, London.

15. Damodaran, A. (2010): Applied Corporate Finance. John Wiley \& Sons Inc. Hoboken.

16. Daróczi, M. (2004): Mezőgazdasági beruházások komplex döntés-elökészítése. Doktori (Phd) disszertáció. 139 p. Szent istván Egyetem, Gödöllő

17. Dudley, C. L., Jr. (1972): A Note on Reinvestment Assumptions in Choosing between Net Present Value and Internal Rate of Return. The Journal of Finance. Volume 27, Number 4 (Sep.), pp. 907-915.

18. Fisher, I. (1930): The Theory of Interest. Macmillan, New York.

19. Garrison, R. H. (1988): Managerial Accounting. Concepts for Planning, Control, Decision Making. Business Publications, Inc. Plano, Texas.

20. Helfert, E. A. (1991): Techniques of Financial Analysis. Business One Irwin. USA.

21. Hill, A. R. (2008): Strategic Financial Management. available at: www.bookboon.com

22. Illés, B. Cs. (2000): A beruházás-gazdaságossági elemzés alapjai. In: Agrárgazdasági élelmiszerelőállító üzem (eds.: Berszán G.-Várszegi T.), Agroinform Kiadó, Budapest, pp. 344-359.

23. Illés, B. Cs., Keszthelyi, Sz. (1998): Mezőgazdasági kis- és középvállalkozások beruházásainak gazdaságossági-, és kockázatelemzése; Tudományos Közlemények - Gödöllöi Agrártudományi Egyetem Gazdaság- és Társadalomtudományi Kar 3: pp. 105-109.

24. Illés, M. (1990): A gazdaságossági és jövedelmezőségi számítások alapjai. (Fundamentals of investment project evaluations and profitability calculations.) Szakszervezetek Gazdaság- és Társadalomkutató Intézete, Budapest.

25. Illés, M. (2007): Scientific problems of modern approach of net present value. Theory, Methodology, Practice. Club of Economics in Miskolc. Volume 4.Number 1, pp. 29-35.

26. Illés, M. (2012a): Transforming the Net Present Value for a Comparable One. Theory, Methodology, Practice. Club of Economics in Miskolc. Volume 8 Number 1, pp. 24-32.

27. Illés, M. (2012b): Links Between Net Present Value and Shareholder Value form a Business Economics Perspective. Theory Methodology Practice. Club of Economics in Miskolc. Volume. 8, Number 2, pp. 31-36.

28. Illés, M. (2014) Fisher's Rate and Aggregate Capital Needs in Investment Decisions. Theory Methodology Practice. Club of Economics in Miskolc. Volume 10, Number 1, pp. 21-32.

29. Illés, M. (2016): The Real Reinvestment Rate Assumption as a Hidden Pitfall. Theory Methodology Practice. Club of Economics in Miskolc. Volume 12, Number 1, pp. 47-60. http://dx.doi.org/10.18096/TMP.2016.01.06 47

30. Johnston, K., Forbes, S., Hatem, J. J. (2002): Reinvestment Rate Assumptions in Capital Budgeting: A Note. Journal of Economics and Finance Education. Vol. 1, No 2, pp. 28-29.

31. Khan, M.Y, Jain, P.K. (2008) Financial Management. Tata McGrow-Hill, New Delhi 
32. Keane, S. M. (1975) Investment selection criteria: an examination of the theory of the internal rate of return and of the investment discount rate under conditions of uncertainty. $\mathrm{PhD}$ thesis. University of Glasgow.

33. Keane, S.M. (1979): The Internal Rate of Return and the Reinvestment Fallacy. Abacus Vol.15, No. 1, pp. 48-55.

34. Keef, S.P., Roush, M.L. (2001): Discounted Cash Flow Methods and the Fallacious Reinvestment Assumption: A Review of Recent Texts. Accounting Education. Volume: 10 Issue: 1 (Mar), pp.105-116 10 (1) pp. 105-116.

35. Keynes, J.M. (1936): The General Theory of Employment Interest and Money, Harcourt, Brace \& Company, New York,

36. Kinney, M., Raiborn, C. (2011) Cost Accounting: Foundations and Evolutions. SouthWestern, Cengage Learning.

37. Laux, J. (2011): Topics in Finance Part VI - Capital Budgeting. American Journal of Business Education - Volume 4, Number 7 pp. 29-38

38. Lee, A. C., Lee, J. C., Lee, C. F. (2009): Financial Analysis, Planning, and Forecasting: Theory and Application. World Scientific Publishing Co. Pte. Ltd.

39. Lohmann, J.R. (1988): The IRR, NPV and the Fallacy of the Reinvestment Rate Assumptions. The Engineering Economist. Volume 33, Issue 4 pp. 303-330

40. Meyer, R.L. (1979): A Note on Capital Budgeting Techniques and the Reinvestment Rate. The Journal of Finance. Vol. 34, No. 5 (Dec.), pp. 1251-1254.

41. Renshaw, E. (1957): A Note on the Arithmetic of Capital Budgeting Decisions. Journal of Business. Vol. 30, No. 3 (July), pp. 193-201.

42. Rich, S. P., Rose, J. T. (2014): Re-Examining an Old Question: Does the IRR Method Implicitly Assume a Reinvestment Rate? Journal of Financial Education. Vol.10, No.1, pp. 105-116

43. Schmalen, H. (2002): Általános üzleti gazdaságtan. (Universal Business Economics) AxelSpringer Budapest Kiadó.

44. Solomon, E. (1956): The Arithmetic of Capital Budgeting Decisions. Journal of Business. Vol. 29, No. 2 (April), pp. 124-29.

45. Szűcsné Markovics K. (2012): A beruházásgazdaságossági számítások gyakorlatban alkalmazott módszerei (Applied Methods of Investment Project Evaluation in Practice) . Vezetéstudomány, Különszám, pp 97-106.

46. Van Horne, J. C. , Wachowicz, J. M., Jr. (2008): Fundamentals of Financial Management. Pearson Education Limited. Harlow.

47. Volkman D. A. (1997): A consistent yield-based capital budgeting method. Journal of Financial and Strategic Decisions. Volume 10 Number 3, pp. 75-88.

48. Walker, J. S., Check, H. F., Jr., Randall, K. L. (2011): Does the Internal Rate of Return Calculation Require a Reinvestment Rate Assumption? - There Is Still No Consensus, West Chester University: Pennsylvania Economic Association Proceedings Annual Conference, June 3-5, 2010. pp. 118-130.

49. Watson, D., Head, A. (2009): Corporate Finance: Principles and Practice. Pearson Education Limited, Harlow

50. Woods J.C., Randall M. R. (1989): The Net Present Value of Future Investment Opportunities: Its Impact on Shareholder Wealth and Implications for Capital Budgeting Theory. Financial Management, Vol. 18, No. 2, pp. 85-91 